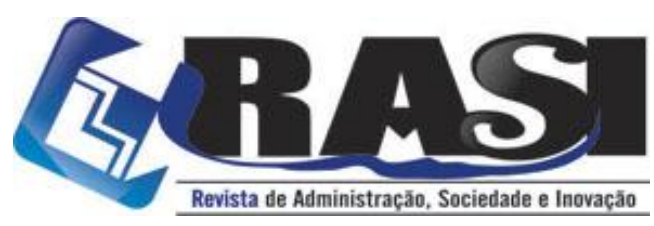

http://www.rasi.uff.br

RASI, Volta Redonda/RJ, v. 4, n. 1, pp. 5-15, jan/jun. 2018

\title{
Always On: tensions between the libertarian ideal and the surveillance and control potential in a hyperconnected society
}

\author{
Gustavo da Silva Motta (UFF) - gustavosmotta@gmail.com \\ Marcos Lima (Léonard de Vinci Pôle Universitaire, Research Center) - marcos.lima@devinci.fr
}

\begin{abstract}
This article sheds light on some of the political and social implications related to the use of mobile devices of communication, such as smartphones and personal digital assistants. Several contemporary phenomena related to the development of a hyperconnected society are presented. Such society is often portrayed as impregnated by the libertarian ideal associated with the development of cyberculture, based on three pillars: freedom of location, freedom of emission and freedom of ideology. The present paper argues that a counter-argument can be derived from Foucault's ideas about surveillance and control, which may be equally categorized by three similar perspectives: surveillance of location, of emission and of ideology. The main underlying objective is to indicate propositions for a larger discussion regarding the power-structure implications of mobile computing in the age of ubiquitous communication.
\end{abstract}

KEYWORDS: Mobility; surveillance and control; freedom; hyperconnected society.

\section{Always On: tensões entre o ideal libertário e o potencial de vigilância e controle em uma sociedade hiperconectada}

RESUMO: Este artigo revela algumas das implicações políticas e sociais relacionadas ao uso de dispositivos móveis de comunicação, como smartphones e assistentes digitais pessoais. Vários fenômenos contemporâneos relacionados ao desenvolvimento de uma sociedade hiperconectada são apresentados. Essa sociedade é frequentemente retratada como impregnada pelo ideal libertário associado ao desenvolvimento da cibercultura, com base em três pilares: liberdade de localização, liberdade de emissão e liberdade ideológica. O presente artigo apresenta contra-argumentos derivados das idéias de Foucault sobre vigilância e controle, que podem ser igualmente categorizados por três perspectivas semelhantes: vigilância de localização, emissão e ideológica. $\mathrm{O}$ principal objetivo é indicar proposições para uma maior discussão sobre as implicações da estrutura de poder da computação móvel na era da comunicação ubíqua.

PALAVRAS-CHAVE: Mobilidade; vigilância e controle; liberdade; sociedade hiperconectada.

R. Desembargador Ellis Hermydio Figueira, 783, Bloco A, sl. 304, Aterrado.
$27213-145$ - Volta Redonda, RJ - Brasil
www.uff.br




\section{Always On: tensions between the libertarian ideal and the surveillance and control potential in a hyperconnected society}

\section{Introduction}

The daily use of mobile communication technology in contemporary urban life calls for a discussion concerning the consequences of augmented mediated interactions both in terms of the so-called "idealized freedom" such mobile devices convey as well as, paradoxically, in terms of its inherent potential for "surveillance and control". In the wake of this problem, some of its specific aspects are to be addressed here: which are the characteristics of this hyper-connected society? How do modern citizens assimilate the use of these mobile devices of communication? To what extent are these devices true to the libertarian ideal and at the same time instruments of surveillance and control?

This discussion is not new. Often the fast adoption rates of media innovations prompt observers to discuss the inherent risks and potentials. One example can be found in the proposal for rethinking the role and use of the mass media in the 1970s (Enzensberger, 1997). Enzensberger (1997) believed in the 'mobilising power' of electronic media. Like Bertold Brecht he argued that the media should be used above all for two-way communication, this being the difference between repressive and emancipatory uses of mass media, as synthesized in the table below (Enzensberger, 1997:173).

\begin{tabular}{|l|l|}
\hline \multicolumn{1}{|c|}{ Repressive media use } & \multicolumn{1}{c|}{ Emancipatory media use } \\
\hline Centrally controlled program & Decentralized programs \\
\hline One transmitter, many receivers & Every receiver a potential transmitter \\
\hline Immobilization of isolated individuals & Mobilization of the masses \\
\hline Passive consumer behavior & Interaction of participants, feedback \\
\hline Depoliticization process & Political learning process \\
\hline Production by specialists & Collective production \\
\hline Control by owners or bureaucrats & Social control through self-organization \\
\hline
\end{tabular}

In order to examine some of the social and political implications of mobile communication devices and their "emancipatory" and "repressive" potentialities, this article analyzes contemporary socio-technical development from the historicist point of view, emphasizing the importance of a historical reflection, as well as positioning it centrally for the understanding of social reality. The daily appropriation of the technique by the urban individual proposes a reflection on the characteristics of the interactions mediated by the communication devices and their contribution to the construction of a new society. Some empirical evidence is presented, in order to prove the reflections proposed here.

This article is divided in three sections. The first presents the basic characteristics of mobile communication in contemporary society, by defining some of the key concepts associated with mobile communication in a hyperconnected society. The second contrasts the libertarian ideal of mobile technology with the underlying power of surveillance and control, based upon the studies of Foucault (2014). The concluding section presents some of the conceptual elements for further discussion. 


\section{A Hyperconnected Society}

The development of mobile technology has, according to several authors (Igarashi, Motoyoshi, Takai, \& Yoshida, 2008; Lemos, 2004, 2007; Mitchell, 2000; Rheingold, 2007) paved the way for the emergence of new social and urban organization forms. In this section, we argue that the advent of communication hypermobility has had an impact in urban spaces, in social interactions, and even in the way humans relate to their bodies.

\subsection{Hypermobility}

Hypermobility can be briefly defined as the capacity to communicate or access data and information anywhere, at any time. It is argued here that the widespread use of mobile devices for communication and interaction seems to be slowly transforming the traditional urban space, affecting how people live, how they work and entertain themselves.

The number of mobile devices that mediate remote communication has been dramatically increased as computational resources are ever more miniaturized. Mediated communication through different types of interconnected personal equipments will be ever more presence in the daily life of modern society. Little by little, computers conquer new frontiers as they are built into other equipments, whose interfaces become more and more intuitive. Smartphones such as the newly released iPhone are a good example of how lastgeneration handheld computers with internet capability are changing the way people relate with their communicational environment, becoming ever less dependent of fix workstations to be able to enjoy the benefits of cyberspace (Lemos, 2004).

Researchers like Rheingold (2007) have developed studies about the "next social revolution" brought about by the diffusion of mobile technology. He has observed changes in the way subjects construct their experience with new communication devices that help reorganize interaction patterns, allowing for direct involvement of individuals with their networks, regardless of time and space limitations. This enables augmented social interactions not only in the realm of technologically mediated communication, but also in face-to-face relationships, as will be further discussed in this article.

Besides human-to-human communication, mobile devices increasingly handle also interaction with other machines. Developments such as the WAP (Wireless Application Protocol) technology present great potential for enhanced mobile communication experiences. The capability of allowing WAP content to be directly pushed to the mobile handset, with minimum user intervention (called "WAP Push"), for example, may allow such applications as guided tours through a historic district, interaction with intelligent household appliances or the use of handheld devices for electronic payments at toll booths or theaters.

Another technology that is broadly used with mobile devices is Bluetooth, which enables inter-machine communication through short radio waves for small distances, with enough bandwidth to transmit high speed data and voice. Besides eliminating cables in machine-to-machine interactions, Bluetooth networks can be set up to recognize specific devices and automatically exchange information with little or no user interference.

Such mobility, which allows people to stay tuned with the specific information flows they choose, which allows people to communicate regardless of time and space limitations, and which allows machine-to-machine interactions with minimum user interference is one of the key enablers of what is being called here a hyperconnected society. 


\subsection{Development of Cybercities}

Digital technology, in its several stages, has been gradually allowing the development of communities with differentiated patterns of sociability, what has been called "cybercities". This word has been used in two different connotations: the digital recreation of actual cities in an idealized cyberspace (such as the "digital city of Amsterdam" project), and to describe urban spaces that begin to experience the emergence hypermobility communication environments. The latter sense is the one described in this article

Levy (2010) portrays cybercities as the collective intelligence or social interactions in cyberspace which emanate from any given territory. Lemos (2004) argues that in the "era of connectivity", characterized by the development of the mobile collective computers, the contemporary cities are transformed into "places of mobility where mobile communication technology begins to be a part of the landscape". In this perspective, the classic conception of urban spaces can not overlook the implications of contemporary socio-technical developments. The future city is not portrayed as a dichotomic space which either denies every bit of influence from the new information and communication technologies, or else is entirely submerged in an atmosphere where digital devices are fully controlled by machines, as suggested by the science-fiction imaginary. The tendency is rather the development of spaces where social interaction is based not only in face-to-face encounters, but also enriched by mobile devices of communication that extrapolate the traditional limits of space, creating "communicational spaces" or "spaces of flux" (Castells, 2009; Lima, Mamede, \& Freitas, 2003) or "digital places" (Horan apud Lemos, 2004).

This process has been taking place since the 1980's, when for the first time modems were used in "Bulletin Board Systems" to connect people asynchronously at a distance, leading to the creation of the first cybercommunities. Today, the popularization of the Internet and the advent of mobile devices have substantially accelerated that tendency, allowing social relationships to take roots "inside" the classic territorial limits, thanks to the availability of portable access points. As discussed by Lemos (2004), with the explosion of mobility, cyberculture is released from its binding cables and becomes omnipresent, so that the user no longer has to search for an access point to the Net; the Net now begins to surround its users in widespread connection availability (Lemos, 2004).

\subsection{Hyperinteractivity}

For several authors, interactivity is defined as a process of bi-directional communication that defies hierarchical patterns of linearity (Couchot, 1997), in which all participants can exchange and negotiate different types of knowledge (Lévy, 2010). Therefore interactivity can be understood as the user's ability to actively participate in the communication process. In an interactive exchange, the user is capable of interfering with actions and reactions, of becoming a receiver and transmitter of messages, creating new roads, new trails, new cartographies in the communication territory (Bettetini, 1996). Such interactivity redefines the roles of the subjects that transit in these territories mediated by devices, signs and, mainly, by countless other subjects.

Rheingold (2007) sees "new" patterns of interactivity arising in the social dynamics of mobile communication. He suggests that mobile devices seem to have a largely unexplored potential to establish social interaction networks through the internet. By hyperinteractivity is meant this ability of such devices to interact with several communication systems (using a range of different connectivity technologies such as WAP, Bluetooth, WI-FI and WIMAX) to 
gain access to different types of networks (the Internet, 4G Networks, intranets, intelligent house systems).

\subsection{Toward the Cyborg?}

How far will the portability of communication devices go in the near future? A few authors, like Stelarc (1997), suggest there is a tendency to embed communication instruments in one's own biological body, so that "the electronic environment will not only generate more information, but will also understand and augment the operational parameters of the body" (Stelarc, 1997; 55). This leads to the perspective of creating unprecedented human-machine interactions known as cyber-organisms or "cyborgs". The term "cyborg" was coined by Manfred E. Clynes and Nathan S. Kline in 1960 to refer to their conception of an enhanced human being capable of self-regulating human-machine systems to survive in outer space.

Examples of that tendency to create cyborg-like mechanisms can be found in research projects related to wearable computing. These studies are based on the idea that there are inherent advantages to operating a computer interface from "inside". These ultra-portable computational devices are activated through intuitive interfaces which respond to body movements in daily activities. This process would be so inconspicuous that users would simply be unaware of an intermediate computational process taking place around them. Such ability to make the medium itself invisible in representing the real is sometimes called "immediacy" (Bolter \& Grusin, 2000) or "zero interface" (Lemos, 1997). As exemplified by Negroponte:

Fashion accessories will take on new roles, becoming some of the most important Internet access points, conveniently surrounding you in a Person Wide Web. How better to receive audio communications than through an earring, or to send spoken messages than through your lapel? Jewelry that is blind, deaf, and dumb just isn't earning its keep. Let's give cuff links a job that justifies their name (Negroponte, [s.d.])

This excerpt does not seem to merely represent some enthusiastic futuristic view by Negroponte, but rather a solid trend. Several researches have led to the development of fabrics that can be used as active screens. Steve Mann became famous for having developed a wearable system consisting of mobile cameras connected to a computer that transmitted images to a visual device placed before his eyes. With the aid of this device, he was able to enlarge his vision capacity, acquiring 360-degree visibility. Considering the fast development of nanotechnology, it seems that the miniaturization and flexibility of computing power will make cyborg applications ever more common, with potential implications to the notions of freedom, surveillance and control.

\section{The Libertarian Ideal}

As Castells (2003) analyses the genesis of Internet, he concludes that one of the fundamental elements for its birth was what he calls libertarian culture, for which two different senses exist: the European and the American. In Europe, the expression refers to a culture or ideology based on the uncompromising defense of the individual freedom as a supreme value in the illuminist tradition. In the American context, 'libertarian' means fundamentally a systematic distrust in the government, based on the idea that the market forces are the best regulators of the economy (Castells, 2003). 
Castells (2003) uses the expression "libertarian culture" in its European sense. He credits the expansion of the Internet culture, among other things, to an ethics based on technomeritocracy, associated with the belief that scientific and technological development is a decisive element in the progress of humanity. This is in line with French Enlightenment principles, according to which opportunities should be the same for all and freedom was understood as the possibility of preserving private interests, without interference from the State. This is in turn aligned with the hacker culture that emerged with the collaborative possibilities of the Internet. This cooperative ethos based on free worldwide communication systems seeks to develop open source alternatives to multinational software products (Himanen, 2001), often viewed by them as capitalist empires whose goal is to control what should be free, namely: information and information systems ${ }^{1}$.

Other authors also credit a lot of liberation potential to the development of digital technology. Lévy $(2001,2007)$ is certainly among those that emphasize the potentiality of the Net to create bridges between people, resulting in some sort of noofphere or collective intelligence. He does recognize, however, that relationships of power permeate all human networks.

The sections below discuss some of the notions of freedom associated with the use of mobile devices of communication, before turning to the potential for surveillance and control which may derive from the same technologies.

\subsection{Freedom of Location}

One of the foremost aspects of what is being called the "libertarian ideal" is the concept of space and the way its perception is affected by the new technologies. Everyday an increasing number of people adopt the use of e-mail, discussion groups, forums, chats, voice over IP, instantaneous messengers and relationship sites. As observed by authors (Castells, 2009; Mitchell, 2000), these meeting places are accessible even far from densely populated areas (even though the digital divide remains a problem in rural areas and developing countries, as discussed further below). Thus, at least conceptually, communication technology has a large potential to reconfigure several layers of daily life in such space-related spheres as the educational, professional, social and political domains. Distance education, home offices, social and political activism all have partially transcended the geographical barriers between transmitters and receptors, making it possible for rural children to learn a foreign language in a developing country, for a real estate broker to operate from his own house and for social or political activists to voice their opinion to a much broader range of supporters.

The mobility of portable devices can take the benefits of this revolution even further. Certain professional domains that rely heavily on logistics as their key success factor (including taxi drivers, transportation companies and autonomous workers) have experienced a true revolution in they way they do business with the advent of the cell phone. For the most sophisticated users, thanks to the omnipresence of free global mapping services over handhelds equipped with GPS (Global Positioning System), it is now possible to find one's way in a perfectly unknown environment even if one lacks the linguistic skills required to ask one's way around.

\footnotetext{
${ }^{1}$ Hackers are commonly mistaken with virtual criminals, whose correct denomination would be crackers. Originally, hackers were skilled computer experts with enough programming skills to create or modify software systems to suit their needs, often making the resulting products open source projects for others to use and adapt.
} 


\subsection{Freedom of Emission}

The freedom of expression is, without any doubt, one of the most important aspects of democracy. Some tools as discussion lists, forums and blogs have given rise to an unprecedented development of computer mediated communities (CMC) aimed at discussing a large variety of subjects: from the personal interest on some specific hobby, such as growing organic products, to political activism and organization of civil rights movements. For Lemos (2006) these manifestations express one of the most striking features of cyberculture: the liberation of the emission pole. Castells (2003) reinforces this perception, recognizing the novel possibility anybody has of finding his/her own destination in the Net, and, not finding it, to create and to publish their own information, thus inducing the creation of a new network (Castells, 2003; 49).

Another phenomenon that has affected the freedom of emission are the peer-to-peer networks (P2P), which allow files to be anonymously exchanged all over the world among countless users, challenging established business models in the phonographic and video industries, for instance, thus threatening the very basis of copyright and authorship principles.

As cell phone cameras increase in popularity and sophistication, photos and videos can be instantly sent to specialized web services that make them available worldwide. This has created legions of amateur reporters and hobby photographers everywhere, making Andy Warhol's prophecy about everyone's fifteen minutes of fame almost a reality.

\subsection{Freedom of Ideology}

This third topic derives, actually, from what has been discussed in the previous topics about freedom of location and of emission. Information and communication technology has allowed people with converging interests to meet and exchange ideas, regardless of their location. The so-called "polyphony of the Internet" facilitates the creation of computer mediated communities (CMC) that can easily attract wordwide supporters with the same political or religious orientation.

One of the most striking examples of how the Internet represents the potential for freedom of ideology is the use neo-nazi and racist groups have been making of it, no matter how hard national governments worldwide have been trying to stop them.

Mobile communication devices can become powerful tools for organizing clandestine rallies or even planning and executing terrorist attacks. The limit to this freedom is, of course, given by the risks of being identified, tracked and monitored by service providers acting under governmental pressure to repress these actions, as discussed below.

\section{Surveillance and Control}

Foucault's perception that communication relationships are intrinsically permeated by relationships of power and surveillance can be used as a counter point to the libertarian vision of the emerging mobile communication technologies.

For the sake of analogy, the analysis of Foucault can be best describe by his reference to the classic architectural project of Jeremy Bentham's Panopticon: This engineering structure was famously designed to become a prison in which guards could see without being seen, inverting the principles of medieval dungeons: rather than to deprive of light and to hide, the panopticon used light and exposure as instruments of surveillance and control visibility as a trap (Foucault, 2014). 
In a hyperconnnected society, the technological apparatuses seem to have the potential to take on the role of a worldwide panopticon. Indeed, as suggested by Foucault (2014), a few resources are necessary for the success of disciplinary power: hierarchical observation, normalizing judgment, and examination (which is seen as combination of the former two resources). All these resources seem to be enhanced through the use of mobile communication technologies.

The author indicates that as social institutions developed, they incorporated the power of surveillance to their processes, instituting supervising roles. Being digitally mediated, the power of surveillance that emerges from mobile devices is potentially greater than physical omnipresence, while attaining an intangible and invisible quality. Modern corporations no longer need "walls" to keep their workers under surveillance and control, their processes don't know longer have to be performed in one place.

The second resource, the use of normalizing judgment, consists of exercising constant pressure upon individuals, in order to force them into conformity. In this perspective, to refuse to become integrated is to choose exclusion. The normalization process, according to Foucault (2014), is one of the great instruments of power. In the case of modern communication technologies, people are increasingly compelled to join the "digital world" lest they be excluded from a series of social benefits, such as: to be able to exercise full citizenship (e-government, electronic vote, tax payment through Internet, etc.); to be able to participate in daily life routines (reading the news, using ATMs, checking the weather); to communicate (e-mail, SMS, voice over IP); and, above all, to be able to consume using electronic processes (e-commerce, e-business, e-auctioning).

Finally, the examination resource, which combines surveillance and normalization, establishes the principle that individuals can be differentiated and sanctioned based on their degree of visibility. The proliferation and the interconnection among so many devices may lead to a scenario in which all mobile users may potentially become observers and, at the same time, objects of observation.

The sections below are an attempt to discuss Foucault's model in terms of the same categories used to present the libertarian potential of mobile technologies, namely: the potential for surveillance of location, of emission and of ideology.

\subsection{Surveillance of Location}

In recent years, a number of services have been offered over the Internet for keeping track of the location of employees, vehicles and stock. All that is needed to trace a mobile phone is a computer with an Internet connection. Once a phone is activated for tracking, it becomes a mobile electronic tag and its approximate position can be followed using the service provider's Web site. While defenders of this technology argue that employees have to consent to being monitored, civil right groups are concerned that there could be privacy and human rights issues surrounding the use of tracking - particularly given the unequal relationship between employee and employer.

Is the instrumental argument that monitoring employees can contribute to improving the effectiveness of logistic processes be enough to override the objections of groups that voice concern over the loss of individual freedom through the surveillance of mobile devices? 


\title{
4.2 Surveillance of Emission
}

Consider the case of Iranian born Hossein Derakhshan (Lemos, 2007). As he applied for a visa to the USA, immigration officials denied his entrance after having researched his name on the Internet and finding out that he kept a blog with critical opinions about the North American government. For (Lemos, 2007), multiplicity of digital devices is creating subtle new forms of control and surveillance. Derakhshan was at the same time a user of the freedom of emission and a victim of the new surveillance and control possibilities which emerged with the new media. Derakhshan's blog was able to create a new territory in cyberspace with his blog, a place of freedom of speech. However, this same "territory" was "invaded" and used against him due to the available surveillance potential of search engines.

Is the freedom of emission potential offset by the possibility of being controlled and punished for the very use of these channels?

\subsection{Surveillance of Ideology}

As previously discussed, the alleged freedom of ideology is enabled by the combination of freedom of location with freedom of emission. In this sense, even in countries where censorship and oppression are obstacles to people's expressions, it is possible to find the means to diffuse ideals using the anonymity of Internet. Likewise, the surveillance of ideology is potentially enabled by the combination of surveillance of location and of emission.

One case in point is the Internet censorship in the People's Republic of China. Using a wide variety of laws and administrative regulations, censorship systems are vigorously implemented by provincial branches of state-owned Internet Service Providers, business companies, and organizations. According to Amnesty International (2004),

\begin{abstract}
there has been a dramatic rise in the number of people detained or sentenced for Internet-related offences, an increase of 60 per cent in 2003 as compared to the previous year's figures. In addition, an unknown number of people remain in detention for disseminating information about the spread of Severe Acute Respiratory Syndrome (SARS) over the Internet. The individuals cited in this report are all considered to be prisoners of conscience. Many have been denied due process and some have been tortured or ill-treated in custody.
\end{abstract}

Are mechanisms to control ideology effective against the ever growing possibilities of freely expressing ideological positions by using communication technologies?

\section{Conclusion}

Seemingly, there is as much potential for freedom of location, of emission and of ideology in mobile technology as for surveillance and control. At the same time that the technological development allows for larger communication flexibility, it also facilitates the appropriation of information as a means of control. Of course the potential for libertarian or repressive ends is not determined by the technology itself, but by how it is appropriated by society.

Whatever the use a society makes of communication technology, one problem remains undisputed in modern day hyperconnnected societies: the deeply excluding character of mobile technologies of communication. In spite of the effort of public policies to create 
programs of digital inclusion, for a long time many of the benefits (and hazards) of mobility will remain restricted to those that have purchasing power to use last-generation portable devices. Even if the cost of those devices is reduced to the point of lowering the entry barrier to millions of users in developing countries, the low educational level of the great majority of users will continue to be a barrier to the enjoyment of the libertarian (and repressive) potential of this technology.

Those considerations reinforce the perception of Foucault (2003) that nothing will change unless the mechanisms of power underlying the structure of society are not modified. It seems desirable to invoke the discussion of these structures rather than to merely turn dogmatically against or enthusiastically in favor of the development of these portable communication networks.

\section{REFERENCES}

AMNESTY INTERNATIONAL. (2004). People's Republic of China--controls Tighten as Internet Activism Grows. Amnesty International, International Secretariat. Recuperado de https://books.google.com.br/books?id=rG65GwAACAAJ

Bettetini, G. (1996). Semiótica, computação gráfica e textualidade. In Parente, A. Imagemmáquina: a era das tecnologias do virtual. Rio de Janeiro: Ed. 34.

Bolter, J. D., \& Grusin, R. (2000). Remediation: Understanding New Media. MIT Press. Recuperado de https://books.google.com.br/books?id=kwZZdKiXG8wC

Castells, M. (2003). A Galáxia Internet: reflexões sobre a Internet, negócios e a sociedade. Jorge Zahar Ed. Recuperado de https://books.google.com.br/books?id=nCKFFmWOnNYC

Castells, M. (2009). The Rise of the Network Society, With a New Preface: The Information Age: Economy, Society, and Culture. Wiley. Recuperado de https://books.google.com.br/books?id=bHsdJWuM3X0C

Couchot, E. (1997). A arte pode ainda ser um relógio que adianta? O autor, a obra e o espectador na hora do tempo real. In Domingues, D. A arte no século XXI: a humanização das tecnologias (p. 374). São Paulo: UNESP.

Enzensberger, H. M. (1997). Baukasten zu einer Theorie der Medien: kritische Diskurse zur

Pressefreiheit. Fischer. Recuperado

de

https://books.google.com.br/books?id=81TzAAAACAAJ

Foucault, M. (2003). Microfísica do poder. Graal. Recuperado de https://books.google.com.br/books?id=eUrPmgEACAAJ

Foucault, M. (2014). Surveiller et punir. Naissance de la prison. Editions Gallimard. Recuperado de https://books.google.com.br/books?id=T5RjAwAAQBAJ

Himanen, P. (2001). The Hacker Ethic and the Spirit of the Information Age. Vintage. Recuperado de https://books.google.com.br/books?id=ERRtQgAACAAJ 
Igarashi, T., Motoyoshi, T., Takai, J., \& Yoshida, T. (2008). No mobile, no life: Selfperception and text-message dependency among Japanese high school students. Computers in Human Behavior, 24(5), 2311-2324. http://doi.org/10.1016/j.chb.2007.12.001

Lemos, A. (1997). Anjos interativos e retribalização do mundo. Sobre interatividade e interfaces digitais.

Lemos, A. (2004). Cibercultura e mobilidade: a era da conexão. Razón y palabra, 41.

Lemos, A. (2006). Les trois lois de la cyberculture. Libération de l'émission, connexion au réseau et reconfiguration culturelle. Societes, 2006(91 1), 37-48. http://doi.org/10.3917/soc.091.48

Lemos, A. (2007). Ciberespaço e Tecnologias Móveis: processos de Territorialização e Desterritorialização na Cibercultura. In Médola, Araújo \& Bruno (orgs). Imagem, Visibilidade e Cultura Midiática (p. 277-293). Porto Alegre: Ed. Sulina.

Lévy, P. (2001). conexão planetária, A. EDITORA 34. Recuperado de https://books.google.com.br/books?id=ANY4crQrTxcC

Lévy, P. (2007). Inteligência coletiva (A). Edições Loyola. Recuperado de https://books.google.com.br/books?id=N9QHkFT_WC4C

Lévy, P. (2010). Cibercultura. EDITORA 34. Recuperado de https://books.google.com.br/books?id=7L29Np0d2YcC

Lima, M. C., Mamede, J., \& Freitas, J. (2003). Espaços de Fluxos em Projetos de Cibercidades. Biblioteca Online de Ciências da Comunicação, 1-16.

Mitchell, W. J. (2000). E-topia: "Urban Life, Jim--but Not as We Know It". MIT Press. Recuperado de https://books.google.com.br/books?id=E2On0MJBItYC

Negroponte, N. ([s.d.]). Wearable computing. Recuperado de http://archives.obsus.com/obs/english/books/nn/bd1201.htm

Rheingold, H. (2007). Smart Mobs: The Next Social Revolution. Basic Books. Recuperado de https://books.google.com.br/books?id=v0ZKQ7aCd2QC

Stelarc. (1997). Das estratégias psicológicas às ciberestratégias: a protética, a robótica e a existência remota. In Domingues, D. A arte no século XXI: a humanização das tecnologias (p. 374). São Paulo: UNESP. 